Original Research Paper

\title{
Pemanfaatan Barang Bekas Sebagai Media Pembelajaran IPA Biologi pada Materi Virus di SMA Muhammadiyah Mataram
}

\author{
Yenni Desimarlina $^{1 *}$, Norma Juniati ${ }^{1}$, Erna Ajizah $^{1}$, Jamaluddin $^{1}$ \\ ${ }^{1}$ Program Studi Magister Pendidikan IPA, Pascasarjana Universitas Mataram, Indonesia
}

DOI: https://doi.org/10.29303/jpmpi.v4i2.655

Sitasi: Desimarlina, Y., Juniati, N., Ajizah, E., \& Jamaluddin. (2021). Pemanfaatan Barang Bekas Sebagai Media Pembelajaran IPA Biologi pada Materi Virus di SMA Muhammadiyah Mataram. Jurnal Pengabdian Magister Pendidikan IPA, 4(2)

Article History

Received: 03 Februari 2021

Revised: 08 Maret 2021

Accepted: 06 April 2021

*Corresponding Author:

Yenni Desimarlina,

Program Studi Magister

Pendidikan IPA, Pascasarjana

Universitas Mataram, Indonesia

Email:

desimarlinayenni@gmail.com

\begin{abstract}
Pengelolaan barang bekas dari lingkungan dapat dimanfaatkan sebagai media pembelajaran yang dapat memicu kreativitas peserta didik dalam kegiatan belajar dan pembelajaran. Kegiatan pengabdian pemanfaatan barang bekas sebagai media pembelajaran IPA telah dilaksanakan pada bulan Februari 2021. Tujuan kegiatan pengabdian yaitu memberikan edukasi kepada peserta didik untuk memanfaatkan barang bekas di sekitar lingkungan sebagai media pembelajaran dan mempraktekkan langsung bagaimana cara pengolahan barang bekas yang bermanfaat sebagai media pembelajaran yang bernilai akademis, praktis, dan ekonomis. Kegiatan pengabdian dilakukan dengan metode demonstrasi dan kegiatan praktek langsung bersama peserta didik di SMA Muhammadiyah Mataram dengan jumlah peserta didik sebanyak 12 orang. Hasil post test dianalisis menggunakan skala linkert dan dihitung menggunakan bantuan Microsoft Office Excel untuk mengetahui sejauh mana minat peserta didik dalam memanfaatkan barang bekas sebagai media pembelajaran dan didapatkan hasil nilai 4,00 dengan kategori "Baik" yang berarti pemanfaat barang bekas sebagai media pembelajaran baik dilakukan untuk menambah minat dan pengetahuan peserta didik. Produk yang dihasilkan dalam kegiatan pengabdian berupa media pembelajaran IPA yaitu struktur virus "bakteriopage".
\end{abstract}

Keywords: Barang Bekas; Media Pembelajaran; Strukur Virus.

\section{Pendahuluan}

Sampah pada dasarnya merupakan suatu bahan yang terbuang dari suatu sumber hasil aktivitas manusia maupun proses-proses alam yang tidak mempunyai nilai ekonomi, bahkan dapat mempunyai nilai yang negatif karena penanganannya, baik untuk membuang atau membersihkannya memerlukan biaya yang cukup besar. Sampah dan pengolaannya kini menjadi hal yang mendesak sebab bila tidak dilakukan penanganan yang baik akan menyebabkan hal yang tidak diharapkan sehingga dapat mencemari lingkungan (Sunarsih, 2018).

Menurut Undang-Undang No 32 Tahun 2009 tentang Perlindungan dan Pengelolaan Lingkungan Hidup, perlindungan dan pengelolaan lingkungan hidup merupakan upaya sistematis dan terpadu yang dilakukan untuk melestarikan fungsi lingkungan hidup dan mencegah terjadinya pencemaran atau kerusakan lingkungan hidup yang meliputi perencanaan, pemanfaatan, pengendalian, 
pemeliharaan, pengawasan dan penegakkan hukum. Berbagai upaya dilakukan untuk memperbaiki atau memulihkan kembali dan meningkatkan kondisi lingkungan yang rusak atau kritis agar dapat berfungsi secara optimal, baik dari unsur produksi dan media alam lingkungan.

Pengelolaan barang bekas dari lingkungan dapat dimanfaatkan sebagai media pembelajaran yang dapat memicu krativitas peserta didik dalam kegiatan belajar dan pembelajaran. Pembelajaran IPA menuntut peserta didik untuk dapat berlaku kreatif dan inovatif dalam memanfaatkan sumber daya alam maupun sumber daya manusia. Konsep kreatif dan inovatif ini sebaiknya tampak dalam kegiatan yang dilakukan di kelas maupun di luar kelas.

SMA Muhammadiyah Mataram merupakan sekolah menangah atas swasta yang berada di wilayah Mataram. Sekolah yang terdiri 4 ruang kelas dengan jumlah peserta didik disetiap kelas kurang lebih 25 peserta didik yang terdiri dari kelas X, XI, XII. Kelas XII terbagi menjadi jurusan IPA dan IPS dengan latar belakang konsentrasi pendidik yang linier. Pelaksanaan kegiatan pembelajaran yang terdapat di SMA Muhammadiyah Mataram sudah sesuai dengan pengimplementasian kurikulum 2013 dengan pendekatan secara konstektual.

Dalam implementasi kurikulum 2013, pendekatan pembelajaran yang dianggap paling sesuai adalah pendekatan konstektual. Pendeketan konstektual adalah konsep yang membantu pendidik mengaitkan konten/materi mata pelajaran sesuai dengan dunia pendidikan. Dengan pendekatan konstektual akan memotivasi peserta didik dalam hubungan antar pengetahuan dan penerapan dalam kehidupan sehari-hari. Dimana, seperti dalam konsep dasar pembelajaran sains, peserta didik diharapkan dapat memberdayakan keterampilan berpikir peserta didik untuk mencapai tujuan pembelajaran yang diharapkan (Muhlisin, et al., 2016). Oleh karena itu, dalam pembelajaran IPA, materi akan lebih mudah diserap oleh peserta didik apabila media pembelajaran menggunakan benda-benda konkrit yang ada di sekitar. Sebagai contoh dalam konsep produktivitas, peserta didik dapat diajak langsung untuk mempraktekkan atau membuat suatu produk dari suatu barang bekas yang bermanfaat dalam membantu peserta didik dalam memahami konsep materi pembelajaran.

Harahap (2019) menyatakan bahwa dengan tersedianya media sebagai bahan ajar yang menarik perhatian peserta didik dan menyenangkan, maka peserta didik akan lebih mudah untuk memahami materi yang disampaikan pendidik dalam kelas. Proses pembelajaran di kelas harus dirancang lebih menarik sehingga dapat meningkatkan minat peserta didik untuk mengembangakan keterampilan peserta didik. Hal ini sejalan dengan Bustami, et al (2018) dan Muhlisin (2019) yang menyatakan bahwa faktor yang mengurangi kurangnya pemahaman konsep adalah karena peserta didik kurang siap untuk mengikuti proses pembelajaran dimana metode, strategi, dan model pembelajaran tidak memfasilitasi peserta didik untuk terlibat aktif dalam proses pembelajaran. Oleh karena itu, pemilihan sebuah media pembelajaran yang tepat sesuai dengan karakteristik pembelajaran IPA menjadi hal yang penting agar proses pembelajaran berjalan dengan lancar.

Berdasarkan uraian di atas, maka diperlukan adanya media sebagai bahan ajar yang dapat menarik perhatian peserta didik melalui kegiatan pengabdian "Pemanfaatan Barang Bekas Sebagai Media Pembelajaran IPA Biologi pada Materi Virus di SMA Muhammadiyah Mataram". Dengan kegiatan pengabdian ini, diharapkan peserta didik dan pendidik dapat memanfaatkan barang bekas sebagai media pembelajaran yang dapat membantu dalam proses pembelajaran.

Masalah literasi saat ini masih menjadi isu yang sangat menarik untuk didiskusikan, termasuk bagi kalangan pondok pesantren mengingat saat ini budaya membaca dan 
menulis yang notabene ciri khasnya di kalangan pondok pesantren sedang mengalami kemunduran. Kemunduran ini disebabkan salah satunya oleh kemajuan teknologi dan informasi. Dampak positif kemajuan teknologi dan informasi bagi kalangan pondok pesantren adalah mudahnya bagi kalangan pondok pesantren untuk mencari sumber belajar atau literatur-literatur keislaman yang dibutuhkan dengan mengakses internet secara mudah dan murah. Selain memberikan dampak positif tersebut, kemajuan teknologi dan informasi juga memberikan dampak negative bagi keberlangsungan literasi di pondok pesantren, yakni malasnya bagi kalangan pondok pesantren untuk membaca terlebih lagi menulis padahal dua hal tersebut adalah tradisi khas dari pondok pesantren.

Gadget memiliki pengaruh besar terhadap kehidupan manusia, demikian pula terhadap anak-anak. Menurut (Mayenti dan Sunita, 2018) bahwa tanpa disadari anak sering menerapkan "What You See is What You Get". Penerapan ini memiliki makna apa yang dilihat oleh anak adalah sebuah pelajaran, apabila tanpa bimbingan yang terarah dan terpadu dari orang tua dan keluarga, perkembangan anak akan mengarah pada sisi negative. Oleh karena itu, orang tua dituntut lebih kreatif dalam mendidik anak, menyediakan sarana bermain, belajar dan media lainnya yang lebih sehat dan sesuai dengan masa tumbuh kembang anak mereka, sebab peran orang tua sangat penting dalam perkembangan teknologi terhadap anak. Orang tua harus cermat dan membimbing anak dalam penggunaan gadget, karena fasilitas yang disediakan oleh gadget tidak hanya menimbulkan dampak positif tetapi juga menimbulkan dampak negatif.

Metode pengenalan konsep lingkungan hidup dapat dilakukan dengan mengadakan sosialisasi pentingnya lingkungan hidup kepada peserta didik. Pentingnya mengadakan penanaman nilai lingkungan hidup saat ini disebabkan rendahnya literasi lingkungan pada peserta didik saat ini, sehingga dengan adanya penanaman pentingnya lingkungan hidup, diharapkan peserta didik mampu menjadi individu yang peduli terhadap lingkungannya, bukan hanya dari segi menjaga kelestarian lingkungan, namun diharapkan juga memiliki kemampuan dalam menjaga perilaku yang baik terhadap masyarakat.

Berdasarkan hal tersebut, peneliti tertarik untuk melakukan pengabdian dengan cara penanaman nilai Pendidikan lingkungan hidup untuk meningkatkan literasi lingkungan melalui sosialisasi dan pengisian angket yang akan diberikan kepada peserta didik jenjang SMA di Ponpes Al-Istiqomah Telagawaru, Labuapi, Lombok Barat.

\section{Metode}

1. Observasi

Observasi bertujuan untuk mengetahui lokasi sekolah, kondisi sekolah, alokasi waktu mata pelajaran yang terkait dan pengantaran Surat Izin Pengabdian tentang "Pemanfaatan Barang Bekas Sebagai Media Pembelajaran IPA Biologi Pada Materi Virus Di SMA Muhammadiyah Mataram" kepada kepala sekolah untuk dibuatkan agenda pelaksanaan.

2. Sosialisasi

Sosialisasi dilakukan untuk memperkenalkan kegiatan pengabdian yaitu memperlihatkan produk berupa struktur virus bakteriofage yang telah dibuat oleh pengabdi kepada peserta didik dengan merecycle barang bekas sebagai media pembelajaran. Pengenalan bahanbahan yang dimanfaatkan dalam pembuatan struktur virus untuk mengedukasi peserta didik dan menjelaskan tujuan dari kegiatan pelatihan yaitu, untuk menumbuhkan kreativitas peserta didik dalam pembuatan media pembelajaran dengan pemanfaatan barang bekas dan menanamkan nilai kepedulian terhadap kelestarian lingkungan dengan mengurangi resude limbah menjadi media pembelajaran yang bernilai akademis, praktis dan ekonomis dengan melakukan reuse terhadap limbah. 
3. Alat dan Bahan

Adapun alat dan bahan pembuatan media pembelajaran berupa struktur virus bakteriofage yaitu:

a. 1 buah botol bekas my zone, sebagai selubung ekor virus bakteriofage dengan pola utuh.

b. 2 buah botol narmada, sebagai kapsid (kepala) virus bakteriofage dipotong terlebih dahulu, ambil 2 sisi atas kedua botol sekitar $10 \mathrm{~cm}$ dan 1 sisi bawah botol sebagai bagian struktur jarum tusuk virus bakteriofage. Kedua sisi atas botol disatukan dan diberikan perekat. Bagian sisi bawah botol akan ditempel dibagian paling dasar sebagai jarum penusuk.

c. 1 buah pita berwarna merah, sebagai strktur asam nukleat (DNA) virus bakteriofage.

d. 1 lembar kartoon, dibuat 2 pola lingkaran. Pola pertama yaitu membentuk lingkaran utuh berfungsi sebagai lempeng dasar struktur virus bakteriofage dan pola kedua pembentuk pola lingkaran yang dilubangi sebagai struktur leher virus bakteriofage.

e. 4 buah kawat dengan panjang $30 \mathrm{~cm}$ sebagai serabut ekor virus bakteriofage.

f. 1 buah lilin digunakan untuk memanaskan kawat agar mudah membentuk serabut ekor dengan cara ditusuk kebgian botol my zone sebagai selubung ekor bakteriofage

g. Korek api untuk menyalakan lilin.

h. Gunting, alat memotong bahan dan pola

i. Cutter, alat bantu memotong bahan dan pola

j. Lem Fox, sebagai bahan perekat antar pola membentuk struktur virus bakteriofage.

k. Tang, alat bantu memotong dan membentuk pola serabut.

4. Metode Praktek
Metode

pelaksanaan

secara

demonstrasi. Pengulasan materi tentang struktur virus bakteriofage kepada peserta didik. Peserta didik dibagi menjadi tiga kelompok dengan masing-masing kelompok terdapat satu pengabdi sebagai tutor pelaksana kegiatan pengabdian. Peserta didik yang telah terbagi menjadi tiga kelompok berjumlah empat orang. Setiap kelompok akan diberikan arahan oleh masing-masing tutor.

Peserta didik dihimbau mengecek kelengkapan alat dan bahan yang akan digunakan. Pengabdi sebagai tutor memberi arahan untuk membuat pola dasar. Pola yang telah dibuat dirangkai sesuai instruksi dari tutor hingga menjadi produk struktur virus bakteriofage yang utuh.

5. Tahap Evaluasi dan Pelaporan

Pelaksanaan evaluasi dilakukan setelah penngabdi melaksanakan kegiatan berupa pengisian lembar angket yang telah disediakan. Lembar angket ditujukan untuk mengetahui minat pengembanngan kreativitas peserta didik terhadap pemanfaatan barang bekas sebagai media pembelajaran setelah mendapat pelatihan. Pelaporan berupa hasil analisis angket yang didapatkan akan dibuat berupa presentasi nilai minat peserta didik dalam pengembangan kreativitas.

6. Analisis Data

Analisis data dilakukan untuk mngetahui sejauh mana minat peserta didik dalam memanfaatkan barang bekas menjadi media pembelajaran IPA khusunya pada materi virus ditunjukkan melalui hasil lembar angket yang telah diisi oleh peserta didik dan dihitung menggunakan skala Linkert dengan interval dengan kategori skala menurut Sugiyono (2013) sebagai berikut : 


\begin{tabular}{|c|c|}
\hline Skala & Kategori \\
\hline $\mathbf{1 , 0 0 - 1 , 8 0}$ & Sangat Tidak Baik \\
\hline $\mathbf{1 , 8 1 - 2 , 6 0}$ & Tidak Baik \\
\hline $\mathbf{2 , 6 1 - 3 , 4 0}$ & Kurang Baik \\
\hline $\mathbf{3 , 4 1 - 4 , 2 0}$ & Baik \\
\hline $\mathbf{4 , 2 1 - 5 , 0 0}$ & Sangat Baik \\
\hline
\end{tabular}

(Sugiyono, 2013)

7. Contoh pemanfaatan barang bekas sebagai media pembelajaran

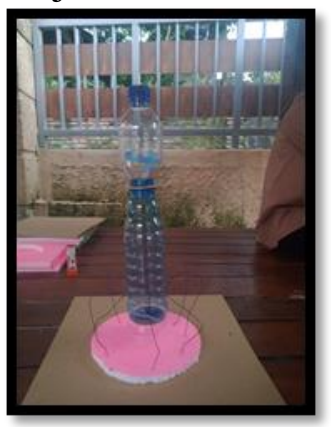

(Gambar 1. Hasil pemanfaatan barang bekas sebagai media pmebelajaran)

\section{Hasil dan Pembahasan}

\section{A. Hasil}

Kegiatan pengabdian pemanfaatan barang bekas sebagai media pembelajaran diikuti oleh 12 orang peserta didik di SMA Muhammadiyah Mataram. Pelaksanaan pengabdian dimulai dari tanggal 18 Februari-22 Februari 2021. Pengabdian untuk memenuhi mata kuliah studi mandiri dilakukan oleh 3 mahasiswa jurusan Pascasarja IPA, Universitas Mataram. Secara umum, kegiatan pengabdian mengenai pembuatan media pembelajaran dengan pemanfaatan barang bekas pada materi virus berjalan lancar. Setelah selesainya pengabdian ini diharapkan pendidik dan peserta didik dapat memanfaatkan barang bekas untuk media pembelajaran IPA sehingga dapat mengurangi pencemaran lingkungan yang ada di sekitar sekolah. Gambaran hasil pengabdian pada setiap tahapan dapat disampaikan sebagai berikut.

1. Koordinasi dengan pihak terkait
Tim pengabdian melakukan koordinasi pihak terkait yaitu koordinator pendidik pada mata pelajaran IPA Biologi SMA di SMA Muhammadiyah Mataram dan mengurus perizinan pelaksanaan kegiatan pengabdian. Koordinasi dengan tim pengabdian dengan guru mata pelajaran dalam mempersiapkan materi serta alat dan bahan yang akan digunkan dalam kegiatan pengabdian.

2. Pelaksanaan pelatihan

Kegiatan pengabdian dilakukan selama kurang lebih 2 jam bertempat di SMA Muhammadiyah Mataram. Tim pengabdian memberikan kegiatan dengan metode demonstrasi agar peserta didik paham langkah apa yang harus dilakukan setelahnya dan menjelaskan materi mengenai virus supaya peserta didik lebih memahami materi yang disampaikan. Tim pengabdian membagi peserta didik menjadi 3 kelompok yang masingmasing 1 kelompok terdiri dari 4 orang peserta didik. Setelah itu kami selaku tim pengabdian yang berjumlah 3 orang mengambil alih tiap masing-masing kelompok sebagai tutor pelaksanaan kegiatan pengabdian bersama peserta didik untuk pembuatan barang bekas menjadi media pembelajaran berupa materi virus. Selama proses berlangsung peserta didik sangat antusias dalam pembuatan barang bekas tersebut menjadi media pembelajaran karena disamping menambah ilmu pengetahuan, juga dapat menambah keterampilan dalam proses sains peserta didik. Pelatihan diakhiri dengan dilakukan post test untuk mengetahui apakah pembuatan media pembelajaran dari barang bekas tersebut baik untuk dilakukan sehingga dapat menambah minat dan pengetahuan peserta didik mengenai media pembelajaran IPA 
setelah mendapatkan pengabdian dari tim pengabdi.

Hasil post test dianalisis menggunakan skala linkert dan dihitung menggunakan bantuan Microsof Office Excel untuk mengetahui sejauh mana minat peserta didik dalam memanfaatkan barang bekas sebagai media pembelajaran. Hasil pengabdian menunjukkan adanya minat peseta didik dalam memanfaatkan barang bekas menjadi media pembelajaran IPA khusunya pada materi virus ditunjukkan melalui hasil post test berskala 4,00 dengan kategori "Baik" yang berarti pembuatan media pembelajaran dari barang bekas tersebut baik untuk dilakukan sehingga dapat menambah minat dan pengetahuan peserta didik. Sedangkan produk yang dihasilkan dalam kegiatan pengabdian ini berupa media pembelajaran IPA yaitu struktur virus "bakteriofage"

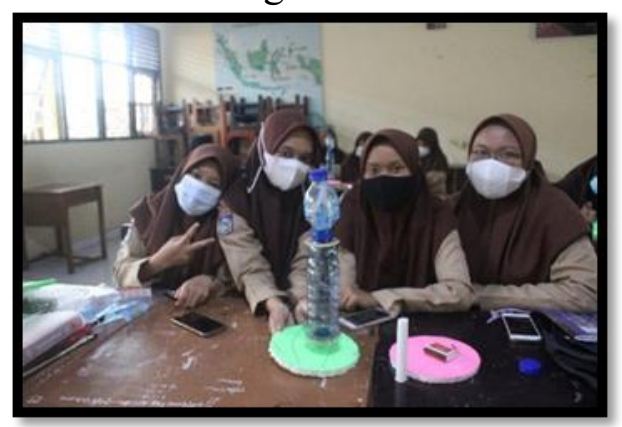

(Gambar 2. Contoh hasil pemanfaat barang bekas sebagai media pembelajaran)

3. Respon Pendidik terhadap Kegiatan Pengabdian

Kegiatan pengabdian pemanfaatan barang bekas untuk dijadikan sebagai media pembelajaran IPA Biologi mendapat sambutan yang luar biasa dari pendidik dari awal hingga akhir pengabdian. Hal ini dikarenakan pengabdian ini menambah wawasan pendidik terhadap pemanfaatan barang bekas menjadi media pembelajaran khususnya media pembelajaran IPA.

\section{B. Pembahasan}

SMA Muhammadiyah merupakan sekolah menengah atas swasta yang berada di mataram. SMA Muhammadiyah Mataram menjadi salah satu sekolah di Kota Mataram yang melaksanakan simulasi pembalajaran secara tatap muka di era New Normal Covid-19, kegiatan pembelajaran di SMA Muhammadiyah Mataram dilaksanakan di kelas dengan mematuhi protokol kesehatan yang ada. Guna melakasanakan proses pembelajaran di sekolah segala bentuk kegiatan akademik dilakukan dengan menaati protocol kesehatan covid-19. Sesuai dengan himbauan dari pemerintah penerapan sosial distancing di kelas telah diakukan dengan baik, dimana setiap tenaga pengajar wajib menggunakan masker. Tidak hanya itu perubahan alokasi waktu pelaksanaan pembelajaran berubah akibat dampak dari Covid-19. Pelaksanaan kegiatan pembelajaran di kelas dimulai pukul 07.30 - 11.00 dengan masing-masing berdurasi 25 menit.

Kegiatan pengabdian merupakan salah satu program mata kuliah studi mandiri. Tujuan kegiatan pengabdian agar mahasiswa dapat mengembangkan atau menerapkan ilmu pengetahuannya sacara nyata baik dalam ruang lingkup masyarakat maupun pada ruang lingkup akademik. Pelaksanaan kegiatan program dilakukan berkelompok dengan program rencana berupa pengayaan atau pelatihan untuk mengedukasi sasaran program pengabdian. Salah satu program kegiatan yang kami lakukan yaitu pengabdian di sekolah dengan sasaran program yaitu peserta didik.

Kegiatan program yaitu untuk mengedukasi peserta didik dalam merecylce barang bekas yang sering mereka jumpai dilingkungan sekitarnya berupa botol plastik yang tidak bernilai menjadi sebuah media pembelajaran yang bernilai akademik, praktis dan ekonomis. 
Kegiatan ini juga bertujuan untuk menumbuhkan minat agar peserta didik mampu mengembangkan kreativitas dan ikut andil dalam membantu mengurangi jumlah produksi limbah yang ada di lingkungan serta membantu menjaga kelestarian alam.

Secara keseluruhan kegiatan pengabdian yang dilakukan oleh mahasiswa Pascasarja Universitas Mataram telah berjalan dengan baik dan lancar sesuai dengan rencana yang telah ditentukan. Sasaran awal program yaitu seluruh peserta didik IPA kelas XII yang berjumlah 15 orang di SMA Muhammadiyah Mataram tetapi hanya 12 orang saja yang telah hadir untuk mengikuti kegiatan pengabdian. Hal ini menunjukkan respon positif peserta didik dalam kegiatan pengabdian pemanfaatan barang bekas sebagai media pembelajaran IPA Biologi di SMA Muhammadiyah Mataram. Kegiatan pengabdian dilakukan selama kurang lebih 2 jam yang dilakukan dengan metode demonstrasi dan dilanjutkan dengan metode praktek langsung oleh peserta didik. Peserta didik sangat tertarik dengan demonstrasi yang diberikan oleh salah satu dari tim pengabdian mengenai pemanfaatan barang bekas sebagai media pembelajaran IPA Biologi dan pendidik mata pelajaran juga berpartisipasi aktif dalam setiap langkah kegiatan pengabdian dengan ikut serta dalam proses pembuatan barang-barang bekas menjadi suatu media pembelajaran IPA Biologi materi virus.

Berdasarkan angket, respon tentang kegiatan pengabdian oleh peserta didik menunjukan bahwa kegiatan pengabdian dengan pemanfaatan barang bekas sebagai media pembelajaran ini sangat menarik karena selain menambah ilmu pengetahuan juga dapat melatih keterampilan proses sains peserta didik. Pada proses kegiatan pengabdian terdapat faktor pendukung dan penghambat untuk mencapai hasil yang optimal. Adapun yang menjadi faktor pendukung kegaiatan pengabdian sebagai berikut :

1. Antusiasme peserta didik

Antusiasme peserta didik dapat dilihat dari banyaknya peserta didik yang hampir semua jumlah keseluruhan peserta didik kelas XII IPA ikut serta dalam kegiatan pengabdian. Peserta didik sangat aktif dan terampil pada saat pelaksanaan kegiatan pengabdian pemanfaat barang bekas menjadi media pembelajaran yang berlangsung, hal ini dikarenakan peserta didik lebih cepat memahami materi mengenai struktur virus apabila ada media pembelajaran yang digunakan dan dikarenakan peserta didik turut serta dalam pembuatan sehingga pendidik dapat juga melihat bagaimana keterampilan proses sains dari masing-masing peserta didik.

2. Antusiasme peserta di sikap pendidik yang mau menggunakan media pembelajaran IPA dari barang bekas untuk kegiatan pembelajaran di sekolah SMA Muhammadiyah Mataram

Kemauan pendidik untuk memanfaatkan barang bekas sebagai media pembelajaran IPA dapat meningkatkan kualitas pembelajaran di SMA Muhammadiyah Mataram sehingga peserta didik mendapatkan pengalaman dalam belajar IPA, karena pembelajaran IPA sangat memerlukan media dalam proses belajarnya. Kreativitas pendidik dalam merecyle barang bekas menjadi sebuah media pembelajaran tidak hanya dapat dibuat pada materi pembelajaran virus saja, namun dapat juga diterapkan pada materi pelajaran yang lain untuk membantu pemahaman peserta didik dalam proses pembelajaran.

Adapun yang menjadi faktor penghambat dalam kegiatan pemanfaatan barang bekas sebagai media pembelajaran IPA Biologi materi virus di sekolah sebagai berikut:

1. Kurangnya fasilitas sekolah

Kurangnya fasilitas sekolah dapat memicu terhambatnya penyampaian materi ajar dalam proses pembelajaran. Kurangnya fasilitas pendukung berupa LCD mengharuskan pengabdi menjelaskan 
materi virus menggunakan metode ceramah dan menulis di papan.

2. Keterbatasan media

Keterbatasan media dalam proses pembelajaran merupakan salah satu faktor yang dapat mempengaruhi proses pemahaman peserta didik dalam memahami materi. Media pelajaran yang dibuat dalam pengabdian hanya fokus pada media pembelajaran IPA materi virus saja, padahal pemanfaatan barang bekas sebagai media pembelajaran dapat digunakan pada materi pembelajaran selain IPA.

\section{Kesimpulan}

Kesimpulan yang dapat diperoleh dari kegiatan pengabdian pemanfaatan barang bekas sebagai media pembelajaran IPA Biologi sebagai berikut :

1. Pemanfaatan barang bekas sebagai media pembelajaran IPA Biologi materi virus menjadi salah satu tambahan alternatif media pembelajaran untuk membantu pemahaman peserta didik di SMA Muhammadiyah Mataram.

2. Pengedukasian peserta didik dalam merecyle barang bekas berupa limbah plastik untuk membatu mengurangi jumlah produksi limbah serta membantu menjaga kelestarian alam.

3. Hasil pengabdian menunjukkan adanya minat peserta didik dalam memanfaatkan barang bekas menjadi media pembelajaran IPA khusunya pada materi virus ditunjukkan melalui hasil post test berskala 4,00 dengan kategori "Baik" yang berarti pembuatan media pembelajaran dari barang bekas tersebut baik untuk dilakukan sehingga dapat menambah minat dan pengetahuan peserta didik

4. Pemanfaatan barang bekas sebagai media pembelajaran tidak hanya dapat diaplikasikan pada satu materi saja, namun juga dapat dikembangkan pada materi yang lainnya.

\section{Ucapan terima kasih}

Ucapan terimakasih kepada Bapak Dr. Drs. Abdul Syukur M.Si dan Bapak Dr. Jamaluddin,
M.Pd karena telah membimbing kami dalam kegiatan pengabdian ini.

\section{Daftar Pustaka}

Ansori, M. \& Martono, M. 2009. Biologi Untuk Sekolah Menengah Atas (SMA) Madrasah Aliah (MA). Pusat Perbukuan Departemen Pendidikan, Jakarta.

Bustami, Y., Syafruddin, D., \& Afriani, R. (2018). The implementation of contextual learning to enhance biology students' critical thinking skills. Jurnal Pendidikan IPA Indonesia, 7(4), 451-457. DOI: 10.15294/jpii.v7i4.11721.

Harahap, H.S. (2019). Pengembangan Media ajar interaktif biologi berbasis macromedia flash dalam komputer pada materi sistem pernapasan manusia. Jurnal pembelajaran dan biologi nukleus, 5(2), 54-66. DOI : 10.36987/jpbn.v5i2.1356.

Muhlisin, A., Susilo, H., Amin, M., \& Rohman, F. (2016). Improving critical thinking skills of college students through rms model for learning basic concepts in science. AsiaPacific Forum on Science Learning \& Teaching, $\quad$ 17(1). https://www.eduhk.hk/apfslt/download/v17 _issue1_files/ muhlisin.pdf.

Muhlisin, A. (2019). Reading, mind mapping, and sharing (rms): innovation of new learning model on science lecture to improve understanding concepts. Journal for the Education of Gifted Young Scientists, 7(2), 323-340. DOI: 10.17478/jegys.570501.

Undang-Undang No. 32 Tahun 2009 Tentang Perlindungan dan Pengelolaan Lingkungan Hidup.

Sugiyono. (2013). Metode Penelitian Pendidikan Pendekatan Kuantitatif, Kualitatif dan $R \& D$. Bandung: Alfabeta.

Sunarsih, L. E. 2018. Penanggulangan Limbah. Deepiblish, Yogyakarta. 